\title{
Farming ethics in practice: from freedom to professional moral autonomy for farmers
}

\author{
Franck L. B. Meijboom ${ }^{1} \cdot$ Frans R. Stafleu ${ }^{2}$
}

Accepted: 1 May 2015/Published online: 4 August 2015

(c) The Author(s) 2015. This article is published with open access at Springerlink.com

\begin{abstract}
Food production, water management, land use, and animal and public health are all topics of extensive public debate. These themes are linked to the core activities of the agricultural sector, and more specifically to the work of farmers. Nonetheless, the ethical discussions are mostly initiated by interest groups in society rather than by farmers. At least in Europe, consumer organizations and animal welfare and environmental organizations are more present in the public debate than farmers. This is not how it should be. First, because consumers often cannot but rely on agriculture. Second, because recent research shows that farmers have moral beliefs and convictions that appear to be broader than economic considerations and that are- - to a certain extent-specific to their profession. This raises the question how to make input from farmers operational in the public debates on the future of farming. We discuss one option: entrusting farmers with professional autonomy concerning moral matters related to farming. We sketch the historical background of the current situation in which farmers are relatively silent on moral matters and we present some clear indications that farmers have values and moral beliefs that are relevant for the public debate. Next the concepts of professionalism and professional autonomy are discussed and applied to the practice of farming.
\end{abstract}

Franck L. B. Meijboom

f.1.b.meijboom@uu.nl

Frans R. Stafleu

f.r.stafleu@uu.nl

1 Ethics Institute and Faculty of Veterinary Medicine, Utrecht University, Janskerkhof 13a, 3512 BL Utrecht,

The Netherlands

2 Ethics Institute, Utrecht University, Janskerkhof 13a, 3512 BL Utrecht, The Netherlands
Finally, we discuss the relevance and limits of professional moral autonomy for the agricultural profession. We close with an overview of what this moral autonomy implies for and requires from farmers in practice. We conclude that if some preconditions are met by farmers, then this type of moral autonomy can be relevant for farmers and for society, and contributes to the quality of the public debate on the future of farming.

Keywords Professional ethics · Autonomy - Public debate $\cdot$ Farmers

\section{Introduction}

Food production, water management, land use, and animal and public health are all topics of extensive public debate. These themes are of great relevance for the core activities of the agricultural and food sector, and more specifically to the work of farmers. At least in Europe however consumer organizations, animal welfare organizations and environmental organizations are more present in the public debate than the farmers themselves. These interest groups initiate the ethical discussions, rather than the farmers.

The public debate on animal welfare can illustrate this point. Since publications such as Ruth Harrison's Animal Machines (1964) and the subsequent studies on animal welfare, such as the well-known report by the Brambell committee (1965), animal welfare has become a subject of public debate. In this debate farmers tended to focus on the technical, rather than on the ethical side of the matter (e.g., Te Velde et al. 2002; Fraser et al. 1997). They discussed the empirical question whether the welfare of the farm animals was indeed harmed-which implicitly recognizes the prima facie wrongness of harming animals. However, 
they often missed the more profound discussions on the moral position of animals and the future of animal production. As a result, in many European societies other stakeholders started to reflect on what is "right" with respect to animal welfare. These groups do not deny the role of farmers with regard to animal welfare, but they do not consider them to be competent partners in the ethical debate on animal welfare. This is a lamentable situation, for a number of reasons.

First, the absence of farmers in the public debate is a fundamental problem. Access to and opportunity to influence the public debate are essential preconditions for a well-operating public discourse (cf. Habermas 1990; Van Mill 1996). Therefore, as citizens and as stakeholders, farmers should have the opportunity to function as full partners in the public debates on issues of agriculture and food production.

Second, the increasing distance in time and space between consumer and farmer entails that consumers are less familiar with agricultural activities and processes (Lang 1999; Mcelwee and Annibal 2010). Consequently, consumers have to rely on farmers in many matters of agriculture because they lack the expertise and time to control all activities in the agro-food sector (Brom 2000; Meijboom 2008). Society needs the involvement of the agricultural sector. At a minimum level, it is necessary in order to provide input for policy and laws that regulate the activities of farming. Beyond that society can benefit even more from the input from farmers, because of the following two reasons.

Third, we see clear indications that farmers have moral beliefs and values that enable them to contribute to the public debate in a relevant way. Farmers are often considered to lack an independent and contributive view because they are looked upon as being primarily economically driven. Even though we do not deny that economic continuity of the farm is a major concern for farmers, recent research shows that this "economy only" view is a caricature (De Rooij et al. 2010; De Lauwere and De Rooij 2010; Driessen 2012, 2014; Grimm 2010; Cardoso and James 2012). Farmers have moral beliefs and convictions beyond economic considerations. Even stronger, they can contribute to the debate in a way that is-to a certain extent-specific to farmers. On the one hand, they have moral beliefs that others may not bring into the debate, such as notions of caregiving and pride, and moral ideals on good farming (De Rooij et al. 2010; De Lauwere and De Rooij 2010). On the other hand, farmers' contribution can be special because of their hands-on experience in dealing with the ethical questions and problems in agriculture. If these views, beliefs and experiences are not utilized, it is a loss for the quality of the public debate.
Fourth, even though farmers still are no frontrunners in moral discussions, recent initiatives show that they are willing to deal with ethical and societal issues. For instance, in the Netherlands and in Belgium some big breeding cooperatives and national farmers' associations established their own ethical committees (e.g., De Weerd et al. 2012). In their public communication too, farmers associations start to include ethical issues such as animal welfare, food safety, and sustainability (e.g., Boerenbond 2010; ZLTO 2009; Deutschen Bauernverbandes 2011).

In sum, farmers should and can have a voice in the public debate. And they increasingly $d o$, or at least try to contribute to the public debate on ethical issues related to the future of the agriculture and food. Furthermore, society needs the input from farmers because consumers are less familiar with agricultural activities and processes. This raises the question how to use this input from farmers to secure their voice in the public debate and to improve the quality of the public debate on the future of farming. In this article, we discuss one option: entrusting farmers with professional autonomy concerning moral matters. This proposal implies that farmers are entrusted by society with certain levels of professional freedom to deal with ethical questions and problems related to (animal) farming. We aim to answer two related questions: (a) Is entrusting professional autonomy concerning ethical issues helpful to enable farmers to play a more constructive role in public debates on the future of farming? And if so, (b) Do farmers fulfill the conditions to be entrusted by society with such autonomy?

In the next section, we analyze some changes in agriculture during the last century in order to understand why farmers currently play a modest role in public debates.

\section{Changes in agriculture and the influence on farmers' autonomy}

Traditionally, European farmers have been entrepreneurs or tenants who highly value the possession of land and animals, because this is related to independent entrepreneurship (cf. Schoon and Te Grotenhuis 2000). Also, they were relatively independent in their choices how to run their farms. There was only little interference from outside. In other words, traditionally farmers have been relatively independent and largely autonomous entrepreneurs.

This situation, however, changed during the last century and especially since World War II. Food security became an important public goal. All developments in agriculture started to focus on the production of sufficient safe food for all citizens of Europe. To pursue this public goal, governments established food and nutrition policies and 
programs in order to combine and improve the individual capacities of farmers to guarantee food security (cf. Lang 1999, 2010; Knutson et al. 1998). However, this "systematic effort to tackle the age-old challenges such as hunger and production shortages" directly interfered in the daily practice of farmers (Lang 1999, p. 336). The aim to increase food production as rapidly as possible resulted in a new paradigm for agricultural production, characterized by up-scaling, increasing productivity, and rationalization of the production process (Waltner-Toews and Lang 2000, p. 117). Consequently, "agriculture has grown from a primary basic sector of the economy to a secondary technical sector with complex joint interactions with the rest of the economy" (Kunkel 1984, p. 21).

For European farmers this meant that they could no longer operate on an individual basis, but had to comply with the broader national and European legal, political and economic context. The constraints created by the "new economic environment of farming limit what options a farmer has available to him" (Hendrickson and James 2005, p. 270). Many farmers were unable to meet the new technical, political and economic demands and had to quit. This resulted in a gradual and irreversible decrease in the number of agricultural holdings (Eurostat 2010). Those who are still in business focus on raising production and increasing productivity. Consequently, the overall productivity in Europe has not decreased in spite of the reduction of farms (Eurostat 2010). In the US the agricultural sector retained a strong economic position (cf. Knutson et al. 1998). In Europe, however, "partly due to its fragmented agricultural sector", the sector never gained such a central position (Lang 1999, p. 339). Citizens and consumers are less familiar with agricultural activities and processes and the distance between farm and fork kept increasing (Brom et al. 2007). This "marginalization process of agriculture in society" (Mcelwee and Annibal 2010, p. 488) and the concomitant lack of control also meant that citizens and consumers had to rely more on the expertise and competence of farmers. The individual farmer in Europe however was not entrusted with this task; rather, he was increasingly confronted with a loss of his traditional independence and autonomy. Farmers still considered themselves as independent entrepreneurs, yet there was "less room for maneuver due to asphyxiating regulatory schemes (partly imposed by food empires, partly by state agencies)" (Van der Ploeg 2010, p. 104; cf. Hendrickson and James 2005).

Initially, this situation turned out to be rather unproblematic for most partners in the sector, farmers included. This, however, changed as a result of a further development. By the end of the last century, when food security was guaranteed in Europe, the exclusive focus on increasing food production was severely questioned by several groups in society. Agricultural production was no longer only evaluated in terms of output and production, but also in terms of animal welfare, social justice and climate change (cf. Mepham et al. 1995; Brom 2000; Korthals 2004; Gottwald et al. 2010). Publications such as the above-mentioned "Animal Machines" (Harrison 1964), but also "Animal Liberation" mark the start of a sharp criticism of farming in general and especially of the intensive use of animals. Even though the central task of agriculture is still food production, a "transition to agricultural sustainability" is considered as essential for the future of agriculture (Ruttan 1999, p. 5960). Consequently, rather than only technical and economic aspects of (animal) farming, a broader range of moral dimensions have become central in the public debates on sustainable food production and the future of animal farming. For instance, it suddenly was stressed that the very efficient and intensified way of farming that first was considered to be the best way to develop for agriculture, had become "a major contributor to environmental problems, including greenhouse gas emissions" (Van der Ploeg 2010, p. 100).

To adjust to this shift in focus turned out to be problematic for farmers, which resulted in a modest role in public debates on these societal issues. We argue that this is not the result of indifference, but should be understood in the light of the above-described developments in the agricultural sector. Traditionally farmers have a broad range of moral values and beliefs (Thompson 2013; Rollin 2004). However, the industrialization of agriculture appealed mainly to the role of farmers as entrepreneur and as technical expert, rather than as a stakeholder who discusses value-laden aspects of agriculture in a public arena. Consequently, farmers still had their traditional values, such as stewardship, care, pride, and responsibility. But there was no direct need to introduce them in the public realm, nor was there an incentive to further develop their professional moral framework in the light of the new developments. Hence, when from the 1970s onwards, other stakeholders challenged farmers, farmers lacked experience in ethical debating and in translating their traditional values into the public realm. As a consequence, they were hesitant to introduce their moral beliefs as input for public debates. This hesitance and their concern for the continuity of their farm and the economic pressure under which they have to operate, led to a situation in which farmers often are not considered as full partners in an ethical discussion. They are regularly accused of being "motivated purely by profit, not by any compassion for animals or the traditional ethic of animal care" (Fraser 2001, p. 636). Such accusations make farmers even more hesitant to enter the ethical discussion. In surveys, farmers mention that they experience a gap between them and the rest of society. They feel that "their farming practice, stimulated by years of agricultural policy, is rejected now" (Schoon and Te Grotenhuis 2000, p. 22). 
In summary, the brief overview of the developments in farming during the last century indicates a mismatch between farmers' traditional values and the modern ethical questions. This explains the loss of "voice" of farmers in public debates on ethical issues such as animal welfare, water management, public health or food quality. Furthermore, the mismatch between farmers and society has an impact on the autonomy of farmers. The traditional conceptions no longer suffice, and, as Rollin (2004, p. 955) accurately argues, "professions must stay in accord with social ethics, or risk losing their autonomy".

Following recent research on farmers' value assumptions and ethical frameworks (De Rooij et al. 2010; De Lauwere and De Rooij 2010; Cardoso and James 2012; Driessen 2014; Stafleu et al. 2004), we argue that farmers can (and more often do) stay in accord with social ethics and that their (traditional) set of values and beliefs can be of added value to the public debate. This, however, supposes that (a) farmers act as professionals and that (b) society acknowledges them as full partners with regard to ethical issues. With this latter point, it is important to note that in spite of the "increasingly urbanized world the rural has not only refused to 'fade away' but has found voice in interesting and to some extent unexpected ways" (McDonagh 2013, p. 715). In this paper, we will focus on the first precondition. Therefore, the next section discusses the concepts of profession and professionals.

\section{Professionals, autonomy and morality}

The autonomy of farmers concerning moral matters that we focus on in this paper is part of a broader discussion on the autonomy of agents in their role as professionals. Already in the 1950s it has been analyzed that work becomes an occupation and some occupations become professions (Evetts and Buchner-Jeziorska 1997, p. 239). Traditionally only medicine and law were seen as true examples of professions. However, currently there is an "increased use [of profession and professionalism] in all work contexts" (Evetts 2003, p. 396). Not only physicians and lawyers are seen as professionals, but also other occupational groups have become professionals, such as those working in the IT sector or journalists.

In practice it is not that easy to distinguish professions from occupational groups. According to the definition of Parsons, a profession is "a cluster of 'occupational' roles, that is, roles in which the incumbents perform certain functions valued in the society in general, and by these activities, typically 'earn a living' at a 'fulltime job", (Parsons 1954, p. 372). From this perspective many occupations can be considered as professions. Consequently,
Wilensky (1964) even wondered whether we could speak of the professionalization of virtually everyone. In reply to this, many authors try to be more specific and identify additional essential elements in order to define a profession, such as education, a legal standing, an internal organization, and an ethical code (Abbott 1988; Dingwall and Lewis 1983; Evetts 2003; Wilensky 1964). In spite of the relevance of these criteria, we agree with Evetts, who follows Hughes (1958) in saying that the differences between professions and occupations are differences of degree rather than of kind (Evetts 2003, p. 397).

Traditionally, expertise and knowledge are considered to be the constitutive elements of a profession. This explains the special position of professions in society. Members of a profession have knowledge and skills with respect to a certain practice that others in society lack. As a result, these (lay) persons have to rely on or trust professional workers in their daily life. This reliance does not imply that the actions of professionals are beyond discussion. Professionals have faced genuine criticism during the last decades. The expert judgments of professionals such as medical doctors, lawyers, or scientist have been questioned (Illich 1977). This shows that the fact that "some professionals are rewarded with authority, privileged rewards and higher status" (Evetts 2006, p. 132) is not unconditional and not based on their expert knowledge alone. As Evetts claims, "professionalism requires professionals to be worthy of that trust, to maintain confidentiality and not use their knowledge for evil purposes" (2006, p. 132; 2003, p. 400). If and only if these conditions are met, another related concept surfaces: professional autonomy.

Professional autonomy is historically considered to be the right to "determine work activity on the basis of professional judgment". This right is granted through public acceptance of the profession's claims with respect to their expertise and service orientation (Haug and Sussman 1969, p. 153). Rollin describes it as a situation in which society says: "You regulate yourselves the way we would regulate you if we understood what you do, which we don't. But we will know if you don't self-regulate properly and then we will regulate you, despite our lack of understanding" (Rollin 2004, p. 955). In practice, this professional self-regulation implies at least that an individual professional is free to make his or her own judgment. For instance, that a journalist can do her work without direct political constraints or that a physician has the freedom to choose the treatment she considers most appropriate based on her professional judgment. In this sense professional autonomy is a minimal condition to function as a professional; it is also a necessary condition if people are to rely on the professional. As Bayles rightly argues, "if professionals did not exercise their judgment in these aspects, people would have little reason to hire them" (1988, p. 28). 
Furthermore, professional autonomy is related to ethical issues (cf. Beauchamp and Childress 2001). This entails certain levels of freedom to deal with ethical issues that are related to the profession, such as end of life decisions by physicians, or dealing with questions of privacy by journalists. This, however, supposes more than mere knowledge and experience. In his analysis of professionalism, Carr (1999) provides a list of criteria that pays explicit attention to the ethical aspects of professions:

(i) Professions provide an important public service;

(ii) They involve a theoretical as well as practical grounded expertise; (iii) they have a distinct ethical dimension which calls for expression in a code of practice; (iv) they require organization and regulation for purposes of recruitment and discipline; (v) professionals require a high degree of individual autonomy-independence of judgment-for effective practice. (p. 34)

According to Carr a profession is intrinsically linked to a public service that has an ethical dimension and touches upon basic rights (1999, p. 37), for example the right to life in the case of medical doctors or the right to liberty and freedom in the case of lawyers. Professionals, in Carr's sense, deal in their daily practice with ethical questions and as such play an important role in addressing these questions. Consequently, a professional needs moral competence. That competence should include more than obeying the ethical code or code of that profession. The "precise codification or systematization of professional ethics" is important, but there still is an obligation for the professional to make his own moral judgment rather than "accept merely at the bidding of others" (Carr 1999, p. 45). If the moral competence of the professional is perceived in this broader sense, professionals can play an active role in dealing with the ethical questions of their professional practice. This makes the claim by Dingwall and Lewis (1983, p. 5) more plausible that "professions and occupations presume to tell the rest of their society what is good and right for it, but also they determine the ways of thinking about problems which fall in their domain". The ability to tell what is good and right is not merely based on knowledge and technical competence, but should also be based on the professionals' moral competence and expertise.

Carr's claim that professions are intrinsically linked to a public service with an ethical dimension is of direct influence on the discussion on professional autonomy. For professionals,

(a) whose profession includes a public service that has an ethical dimension and (b) who have the moral competence and expertise to deal with this dimension,

professional autonomy can include certain levels of freedom concerning moral matters related to the profession. This is what we call "professional moral autonomy" (PMA).

\section{Professional moral autonomy: its limits and relevance}

Dealing with moral questions is often part and parcel of a profession. Scientists, for instance, have to manage conflicts of interest; bankers have to deal with questions of responsible finance; farmers confront conflicts between animal welfare and economic considerations. This, however, does not immediately explain the need for professional freedom concerning moral matters. To trace the relevance of PMA it is helpful to specify its limits. We identify at least three cases in which PMA does not play a central role.

First, there are ethical questions that do not require any moral freedom. For instance, professionals are not free in answering the question whether or not to plagiarize in science or whether a farmer needs to notify the authorities about a zoonotic disease on his farm. On such topics there is legislation that equally or even specifically holds for professionals. Second, PMA is not at stake if the ethical issue related to a profession belongs to the realm of private morality. For instance, a professional can be free with respect to the professional partners he chooses or the friends he makes. However, this moral freedom is not because it is entrusted to him as a professional. It is a freedom one has as an individual citizen and that can be used in onés role as a professional.

Third, the notion of deliberately entrusting PMA appears to be superfluous if issues related to a professional practice are moral by nature, but do not lead to ethical problems. For instance, we expect a medical doctor to be on time for her consults and to deal with emergency cases. If these two expectations conflict, she of course has freedom to assess the situation at stake. However, it would be too strong a claim to say that we deliberately entrust her with moral autonomy to deal with problems of agenda setting in cases of emergency even though principles of justice and benevolence are at stake. In most Western societies we commonly share the view that emergency cases have priority even if this implies that one has to cancel less urgent consults and we expect the physician to act similarly.

Having sketched its limits, we can define when PMA is relevant for professionals and for the public that has to rely 
on those professionals. This is the case if ethical issues related to a profession:

(a) are on the public agenda,

(b) are not (yet) fully governed by laws, and

(c) lack a shared moral understanding in society.

Confronted with themes and questions that meet these criteria PMA can be relevant. It is possible to be even more precise by defining three situations in which PMA is relevant. First, it is relevant if professionals have to deal with ethical questions, but cannot have in-depth discussion with society prior to their actual decisions. For instance, a veterinarian working in a shelter makes moral decisions on a daily basis, but she cannot always discuss her options at full length as these decisions are often made under time constraints. So a complete lack of freedom for professional moral judgment would almost paralyze such a practice. However, as a response one may argue that this situation asks for a clear ethical code of conduct rather than for entrusting professionals with moral autonomy. Although having a professional code is a precondition for PMA (Carr 1999), no general rule can completely prescribe how a professional should act. The well-known four principles of biomedical ethics (Beauchamp and Childress 2001) are a clear example. Even if we agree on, for instance, the importance of the principle of benevolence, it is not selfevident how a professional in a specific context should interpret this principle. Professional practices ask for the power of judgment in order to come to tailor-made interpretations of ethical principles in the context of a specific situation. In this context, PMA is essential as it provides professionals with the room to specify the interpretation of (broadly shared) principles for their practice.

Second, PMA can be relevant if discussions on ethical questions are still open-ended. This open or on-going character of the public debate can have different origins. On the one hand, it might be the result of a generally accepted plurality of views with respect to an ethical issue. In that case PMA implies that professionals have the freedom to operate within the field of existing and accepted moral positions. This enables a medical doctor, for instance, to deal with practical requests for cosmetic surgery in spite of the diversity of views on the importance and need of this kind of surgery. On the other hand, professionals often operate in fields that are characterized by innovation and transition. Consequently, the ethical problems are not restricted to questions of interpretation, but also include genuine controversies or lacking clarity about what principles are applicable and about the professionals' responsibility. As a result, public debates are quite often characterized by a plurality of conflicting or even mutually exclusive views. For instance, the ethical dimensions related to euthanasia, legal justice or animal welfare are broadly recognized. Nonetheless, we often lack consensus on the best way to address these issues. In those situations, PMA is relevant. At this point, however, one could argue that this asks for legislation rather than professional autonomy. In the end this may be true. Nonetheless, if a practice is characterized by profound moral plurality, then formulating policy and legislation is not only difficult, it also raises questions with regard to the legitimacy of the legal framework. Therefore, next to or parallel to the process of policy building it is important to focus on autonomy in order to prevent that we end up with "ill-conceived legislation" (cf. Rollin 2004, p. 964). This also shows that professional moral autonomy can never be a blank check to deal with controversial ethical issues. It is an indexed freedom to explore various options that are available and that are discussed in the public debate. This enables professionals to contribute to the public debate by sharing experiences and showing best practices. For instance, it can imply pilot projects on data protection by ICT professionals or nanotechnology by scientists.

Finally, PMA is important if professionals have to act in spite of the moral controversies. A veterinarian, for example, is confronted with public opinion against unsedated castration of male piglets and with practical requests of farmers on this issue. Therefore, some professional autonomy is necessary to function as a professional. In this way they can "determine the ways of thinking about problems which fall in their domain" (Dingwall and Lewis 1983, p. 5).

\section{The future of farming and the relevance of PMA}

Having outlined the contexts in which professional moral autonomy is relevant, we can focus on the applicability of this concept for the practice of agriculture. We argued that PMA is relevant if a profession is confronted with problems that have a public dimension, that are not (yet) fully governed by law, and about which there is not (yet) a shared moral understanding in society.

With regard to the first criterion, it is evident that farming is linked to a number of public goods, such as food security and safety, land use, spatial planning and nature management. Consequently, farmers often are confronted with questions that have a clear public dimension. Even questions that seem to start on an individual farmer's level often have a public dimension. For example, a laying hen farmer needs to make a decision whether or not to kill a couple of hens that are ill and can easily be treated, but even after treatment may be a small health risk to the thousands of other hens. Even though the farmer's choice is on a private level, the options he has are immediately framed by broader public themes on housing systems, 
animal welfare, the use of antibiotics and public health, and the price of eggs.

Second, we argued that PMA is relevant if a profession lacks sufficient guidance from a legal framework. With regard to this condition it is less clear whether PMA is relevant for the farming practice. Because of the public importance of food security, food safety, and public health there are already many laws and directives that guide farming practice. For instance, if the farmer in the abovementioned example would like to use battery cages to address the health risks, he is not allowed to use this housing system in Europe because of the EU ban on battery cages (EC 1999). Nonetheless, there still are themes that are not fully governed by legal frameworks, such as animal welfare, farming styles and the use of technologies.

This leads to the third condition that defines whether PMA is relevant: the absence of a shared moral understanding in society. In farming there are quite a few themes that meet this criterion. It is possible to distinguish between two different categories. First, there are topics that are essential to farming, but controversial in society, such as the moral ideals on farming styles (conventional or organic), the acceptability of dehorning cattle or the use of antibiotics (cf. Cardoso and James 2012). Second, there are discussions on topics that are relatively new for farming, e.g., because technologies become available for agriculture or because of new expectations and views on responsibilities toward agriculture (e.g., with respect to water management and climate change). The plurality of views on the role that technology should play in the future of animal production is a good example. While some emphasize the need to use new technologies, others stress the importance of natural processes that should remain untouched by technology. However, even those who agree on the general importance of technology may differ profoundly in their view on why technology is relevant. Some argue that technology is necessary to make the current intensive animal farming more sustainable. Others see technology as the way to abandon animal production by searching for alternative sources of protein, such as in vitro meat (Van der Weele and Driessen 2013). The outcome of these discussions is still uncertain, as the ethical standards on a number of topics are not yet set.

The discussion of the three conditions that define whether PMA is relevant shows that, essentially, this notion of autonomy is applicable to the practice of agriculture. It would however be too easy to claim that therefore the individual farmer needs PMA. To make that claim, it should be clear that farmers are worth to be entrusted with professional autonomy in terms of room for exploration.

\section{Farmers and the conditions for entrusting PMA}

The relevance of PMA in the context of agriculture is now evident. The next question is whether farmers fulfill the conditions for PMA. From the discussion on professions and professionals, we distinguish three conditions. First, PMA requires that the profession is related to the production or distribution of a public service. Second, PMA supposes that the professional has the moral competence and expertise of the professional to deal with the public dimension. Finally, there are procedural conditions, such as the establishment of an ethical code of practice and a certain level of organization and regulation.

The first question, then, is whether farming includes a public service. The answer appears to be positive. Farming has a long history of contributing to public goods such as food, feed and soil, and more recently the management of nature and water (e.g., Cooper, et al. 2009; Varley et al. 2009; Thompson 1990). This public dimension has also been recognized by individual farmers (cf. De Rooij et al. 2010; De Lauwere and De Rooij 2010), by national farmer associations (cf. LTO-Nederland 2009; NFU 2010), and by governments all over Europe in policy on these topics. On top of this, these public services are characterized by a number of public ethical debates, such as on food production, animal use, sustainable land use and nature management.

The second question is related to the moral competence and expertise of the professional. Whether farmers meet this condition is less self-evident. If we start with the farmers' track record in contributing to ethical debates, the evidence is not really convincing. At the same time, we showed at the start of this paper that there are recent initiatives in the agricultural sector that show that farmers aim to contribute to the public moral debate. In their communication they start to include ethical issues. For instance, one of the Netherlands Farmers Associations stresses in its vision document 2010-2020 that moral reflection on and a reorientation on personal and public values is essential for the members, the board and the staff of the association. To function as farmers in the future, one of the farmer associations argues, it is necessary to reflect "on what we really think to be important, on our passions, and on what we aim to contribute to the society. Answers in terms of technology, management or finance alone no longer suffice" (ZLTO 2009, p. 3). Also initiatives in other countries (cf. Deutschen Bauernverbandes 2011) illustrate that farmers have, or at least are developing competence to deal with the moral dimensions related to their profession. Furthermore, the empirical research that underlies the present article indicates that farmers have moral views that they aim to 
incorporate in their way of farming (De Rooij et al. 2010; De Lauwere and De Rooij 2010; Meijboom 2009; Driessen 2014).

This leaves the third question: can farmers as professionals meet the procedural conditions, such as those defined by Carr (1999)? These conditions are (a) the establishment of an ethical code of practice and (b) a certain level of organization and regulation for purposes of (recruitment and) discipline. At this point, professional organizations for farmers were traditionally focused on promoting farmers' economic interests. While veterinarians and medical doctors since long have ethical codes, farmers are not yet used to act according to general codes of conduct. There certainly are (developments toward) ethical codes and guidelines though, for instance those of the Belgian Farmer Association (Boerenbond 2010; De Winter 2004) and some breeding corporations in Europe (De Weerd et al. 2012; Stafleu 2001; EFFAB 2014). These organizations not only drafted a code, but a number of them also established ethical committees. This indicates that farmers are starting to acknowledge the new moral dimension of their profession and are building the competence to deal with them. However, in comparison to other professions this is still on a minimal level and should be further elaborated by, for instance, teaching, and an improved institutional infrastructure in which attention to ethics is embedded.

Nonetheless, we conclude that basically farmers can and in some cases did meet the conditions to entrust them with PMA. In the next section, we further specify this conclusion, because it is important to differentiate between types of farmers.

\section{Types of farmers and the feasibility of PMA}

In general terms we showed that farmers meet the conditions to be entrusted with PMA. However, we need to add some comment to this general point of view. Although all farmers have to obey the law and have to adhere to an ethical code, professionals have their own style. In the case of farming these differences are relevant, because they determine (a) whether a farmer needs PMA and (b) whether he or she can be entrusted with moral autonomy. This section identifies and presents four types of farmers. The distinction is based on in-depth interviews with a large number of farmers (De Rooij et al. 2010, pp. 344ff; De Lauwere and De Rooij 2010).

A first group consists of so-called "growth-orientated entrepreneurs" who are strongly focused on production. They emphasize the relevance of their profession on a public level, e.g., with respect to food safety. However, they do not recognize any ethical issues concerning this production. They are convinced that public concerns with respect to animal farming are rooted in ignorance, and will be solved with better information. For this group of farmers professional moral autonomy is irrelevant. On the one hand, they do not fulfill the necessary conditions to be entrusted with PMA. On the other hand, they do not need autonomy on moral matters, because they do not recognize the ethical dimension in issues, such as animal welfare of nature management. For this group PMA will not be a relevant tool that enables them to enter the public debate or to empower them in public debates on ethical issues.

A second group consists of idealists who are quite aware of the ethical dimensions of their work. Nonetheless, in practice they are not faced with ethical problems because they start from rather specific moral assumptions that provide them with answers to most of the ethical questions. For instance, they have quite outspoken ideas about the acceptability of mutilations, such as castration or the use of new technologies. Consequently, this group can be entrusted with PMA in the sense that they have the competence and experience to deal with ethical issues. However, it is questionable whether PMA is of any relevance for this group. They do not need any professional freedom to search for their position or deal with plurality. In this sense it is not likely that professional autonomy will be relevant for this group in order to be in a better position to enter the discussion. It is quite likely that they already are involved in public discussions on the ethical aspects of animal farming.

Two other groups can be distinguished that linger in between. They recognize that animal farming raises ethical questions, but they do not (yet) have a clear and direct answer to these questions. A first group consists of farmers who try to "construct an equilibrium between animal welfare and economic interests and prospects" (De Rooij et al. 2010, p. 351). Another group focuses on dialogue and open communication in order to deal with the public concerns with respect to animal farming (p. 354). Especially for these groups PMA is relevant. Farmers who can be classified in these groups are aware of the moral dimensions of their profession and have moral beliefs and convictions that appear to be broader than economic considerations only. Consequently, they can be entrusted with PMA. Furthermore, entrusting these types of farmers with certain levels of freedom in order to deal with ethical questions and problems related to (animal) farming is relevant for the farmer. He or she can use this type of autonomy to explore the available alternatives and to manage the changing expectations toward agriculture as professionals in a socially responsible way. For these types of farmers PMA can be an incentive to enter the public debate and to empower them in public debates on ethical issues. 


\section{PMA in practice}

As a final step, it is now possible to explore what PMA for farmers implies and what it requires in practice. To start with the latter, PMA requires that farmers are aware that any right or privilege linked to this freedom cannot be seen independent from the duty to reflect on the moral dimensions of agriculture and to act as trustworthy partners in moral matters, i.e., as competent and adequately motivated actors. This entails that farmers should act according to the laws, regulations and society's shared moral understandings, but that they also have the competence of moral judgment and discretionary powers to assess a situation if we lack laws or are confronted with genuine moral plurality.

In practice this implies that individual farmers and their professional organizations have to formulate and use ethical codes of conduct that provide practical guidance for the daily practice of farming. On the one hand, these codes have to formulate the values farmers adhere to, e.g., care for animals and the environment, and respect for autonomy of citizens, colleagues and other stakeholders. Such values may still be quite general. On the other hand, the code needs to provide-based on the ethical values-more practical principles and guidelines. For example, it translates the general concern for animal welfare to specific requirements of daily care and inspection of animals. Such a code should be considered as a precondition for PMA, rather than as its replacement. It is a precondition because an ethical code clarifies for farmers when freedom to explore in moral matters is necessary. In addition, it is a precondition because such a code helps to show farmers as partners that can be entrusted with professional freedom. Second, PMA requires that ethics is included in agricultural educational programs of schools and (applied) universities. These programs should provide knowledge of theories and tools to recognize ethical problems, but also practical training to deal with moral questions and public concerns. Finally, attention to ethics should be embedded in the infrastructure of farmers' organizations. This may result in the establishment of ethics committees, but can also be translated in explicit attention to ethics during (annual) meetings. These components contribute to the competence to deal with moral questions, which is essential to work with ethical codes and to actively use the moral autonomy.

To establish and implement ethical frameworks and education in ethics is a task national or regional farmers organizations should take seriously and not only in aspirational, but also in operational terms. If they do so, farmers become trustworthy partners in ethical issues and can be entrusted with PMA. This can be relevant for both farmers and society. First, it can increase efficiency in cases that are controversial. For instance, moral autonomy with regard to the dehorning of cattle is important as long as there is no clear consensus in society. If farmers would lack any moral freedom in those cases, they run the risk that their profession gets paralyzed if self-regulation is replaced by ill-conceived laws. Thus, this freedom can be essential for farmers. However, this self-regulation is relevant for society as well, because PMA comes with a responsibility for farmers to reflect on the normative issue at stake. In this case it implies ethical reflection on dehorning and the responsibility to use this freedom to find (new) ways to cope with the conflicting views on such a topic, e.g., by exploring the alternatives in terms of housing systems or breeding strategies.

This latter point is related to a second way in which PMA works in practice. It can make farmers' experience operational. Farmers have direct and hands-on experience with a number of issues that are publicly debated, such as animal welfare, land use or water management. This experience (in combination with the condition of moral competence) can serve as input to the public debate that other stakeholders cannot easily provide. Furthermore, PMA can be useful to explore and test ideas and innovations that follow from public debates. For instance, farmers can play an essential role in exploring ways to improve animal welfare and weigh this value against other values, such as public health, environmental values and economics. In practice this may result in room for the farmer to explore new housing systems, or feeding or breeding strategies. Furthermore, the room to explore can be used as a first step before a large-scale introduction of new technologies or in the process of drafting policies and regulations.

Finally, PMA for farmers is relevant in order to clarify and deal with mutual expectations between farmers and society. As mentioned above, the position of and expectations toward farmers are changing and are not univocal. It is evident that people expect agriculture to be carried out in an environmentally friendly manner and that parts of society consider farmers as romanticized guardians of the countryside (Mcelwee and Annibal 2010; Dundon 2003). At the same time, farmers are still expected to produce sufficient and safe food in an economically viable way. In addition, the scope of the tasks of agriculture is broadened and can include nature management and water management, the so-called green and blue values of agriculture (SER 2008).

In this context PMA gives farmers the tools to find a balance between accommodation and integrity. Accommodation implies that the farmer should be open to the plurality of moral expectations and should be prepared to change his view, and be willing to actively search for new 
ways to deal with the conflicting expectations. PMA can help in these cases to formulate legitimate reasons for the decision whether or not to comply with the expectation of society. This is directly linked to having integrity. Integrity understood as a sincere commitment of the farmer to "those projects and principles which are constitutive of one's core identity" or with the tasks and aims that are constitutive for agriculture, leads to constraints on the demand of accommodation in a way that make choices not arbitrary. The choices farmers make, based on their professional autonomy, are not beyond debate, but they are well considered choices, and the farmer can give legitimate reasons for the decision whether or not to act in the expected way. Consequently, not everyone in society will agree with farmers, but the profession can be trustworthy despite the confrontation with the changing and conflicting moral expectations (Meijboom 2008).

In sum, PMA can in practice contribute to the efficiency of farmers, helps to make their moral experience operational in the public debate, provides room to explore the feasibility of ideas from public debate, and is a tool to clarify mutual expectations and deal with conflicting expectations.

\section{Conclusion}

We conclude that the relevance of professional moral autonomy arises from the combination of three elements. First, the increasing distance in time and space between consumer and farmer, which implies that society has to rely on farmers in many matters of agriculture because they lack the expertise and time to control all activities in the agro-food sector. Second, the presence of a number of ethical issues on the public agenda that are not (yet) governed by laws and lack a shared moral understanding in society. Third, we have clear indications that farmers have moral beliefs and values that enable them to contribute to the public debate in a relevant way and that they increasingly are willing to contribute to the debate on, for instance, animal welfare, nature management or sustainable food production. Consequently, it can be possible and relevant to entrust farmers with professional freedom in moral matters.

However, we also discussed that PMA can only be entrusted if the professional meets certain conditions. From this perspective, we have to conclude that farmers and their professional organizations have already taken steps, but still have to make further progress in order to gain sufficient competence and experience to deal with the ethical dimensions of their profession. This implies that they have to establish and implement ethical frameworks, address ethical issues in their education programs, and further embed attention to ethics in their professional organization. This is a task national or regional farmers' organizations should take seriously and not only in aspirational, but also in operational terms. In addition, we have to sound one note of caution: for the so-called growth-orientated entrepreneurs, who are strongly focused on production (De Rooij et al. 2010), PMA will not be a useful concept. This is mainly because they are not aware of the moral dimensions of the public issues related to agriculture.

These conditions show that PMA never implies a blank check with respect to moral matters in general. It is always a matter of entrusting professionals in well-delineated cases based on their professional moral beliefs and values, experience and competence. Furthermore, the analysis shows that the discussed conditions are necessary, but not sufficient conditions to entrust moral autonomy to professionals. The autonomy is entrusted by society, a profession cannot enforce it. Nonetheless, a profession can prove society that they are worthy of the autonomy and can show that entrusting PMA is of mutual relevance and benefit in a specific case.

If farmers meet these necessary conditions and thereby prove themselves as trustworthy partners in ethical issues, society has reasons to entrust them with PMA. In practice, this implies that PMA can increase the efficiency of farmers, because they can run their farms in spite of the ongoing debates. Second, it helps to makes their moral experience operational in the public debate, provides room to explore the feasibility of ideas from public debate. Farmers can, for instance, play an important role in exploring ways to deal with questions of nature management in rural areas. Finally, it is a tool to clarify mutual expectations and deal with conflicting expectations.

We conclude that professional moral autonomy is relevant for those farmers who recognize the moral dimension of farming, but are still looking for legitimate moral answers to the public questions related to their profession. Entrusting them with PMA gives an impetus to the search for innovative answers to the ethical questions raised by agriculture. Rather than emphasizing that they lack clear answers, entrusting them with freedom to explore ideas and to make innovations operational contributes to a joint search for ethical answers. In this way the public and the farmers, the agricultural professionals, can strengthen each other.

Acknowledgments This article is part of a research project entitled "A new ethics for livestock farming: towards value based autonomy of farmers?" funded by the Netherlands Organization for Scientific Research. Previous versions of this paper benefited from discussions with colleagues from the Philosophy Department and the Ethics Institute of Utrecht University. Thanks are due to the helpful and relevant comments by the three anonymous reviewers and the editor. 
Open Access This article is distributed under the terms of the Creative Commons Attribution 4.0 International License (http://crea tivecommons.org/licenses/by/4.0/), which permits unrestricted use, distribution, and reproduction in any medium, provided you give appropriate credit to the original author(s) and the source, provide a link to the Creative Commons license, and indicate if changes were made.

\section{References}

Abbott, A. 1988. The system of professions: An essay on the division of expert labour. Chicago, IL: University of Chicago Press.

Bayles, M.D. 1988. The professions. In Ethical issues in professional life, ed. J.C. Callahan, 27-30. New York: Oxford University Press.

Beauchamp, T.L., and J.F. Childress. 2001. Principles of biomedical ethics, 5/e ed. Oxford: Oxford University Press.

Boerenbond (Belgium Farmers Association). 2010. Jaarverslag 2009 (Annual Report) d/2010/0728/05. http://www.boerenbond.be. Accessed 1 Nov 2014.

Brambell, F.W.R. 1965. Report of the Technical Committee to Enquire into the Welfare of Animals kept under Intensive Livestock Husbandry Systems, the Brambell Report. London: HMSO.

Brom, F.W.A. 2000. Food, consumer concerns and trust: Food ethics for a globalizing market. Journal of Agricultural and Environmental Ethics 12(2): 127-139.

Brom, F.W.A., T. Visak, and F.L.B. Meijboom. 2007. Food, citizens and market: The quest for responsible consuming. In Understanding consumers of food products, ed. L. Frewer, and $\mathrm{H}$. van Trijp, 610-623. Cambridge: Woodhead Publishing.

Cardoso, S.P., and H.S. James Jr. 2012. Ethical frameworks and farmer participation in controversial farming practices. Journal of Agricultural and Environmental Ethics 25(3): 377-404.

Carr, D. 1999. Professional education and professional ethics. Journal of Applied Philosophy 16(1): 33-46.

Cooper, T., K. Hart, and D. Baldock. 2009. The provision of public goods through agriculture in the European Union, Report Prepared for DG Agriculture and Rural Development, Contract No 30-CE-0233091/00-28. London: Institute for European Environmental Policy.

De Lauwere, C.C., and S. De Rooij. 2010. Dé ondernemer bestaat niet; Melkveehouders en varkenshouders over hun visie op dierenwelzijn en andere duurzaamheidsaspecten. Publicatie 10-006. Den Haag: LEI Wageningen UR.

De Rooij, S.J.G., C.C. De Lauwere, and J.D. van der Ploeg. 2010. Entrapped in group solidarity? Animal welfare, the ethical positions of farmers and the difficult search for alternatives. Journal of Environmental Policy \& Planning 12(4): 341-361.

De Weerd, M., F.L.B. Meijboom, and J.S. Merton. 2012. Implementation of ethical standards in a cattle improvement company. In Climate change and sustainable development, ed. T. Pothast, et al., 436-438. Wageningen: Wageningen Academic Publishers.

De Winter, P. 2004. Gids voor de goede omgang met landbouwdieren overzicht van de wettelijke bepalingen en richtlijnen. Leuven: Belgische Boerenbond.

Deutschen Bauernverbandes. 2011. Leitbild. des Deutschen Bauernverbandes. Werte und Orientierung für die Zukunft, Berlin: Deutscher Bauernverband e.V. http://media.repro-mayr.de/79/ 542779.pdf. Accessed 29 Apr 2015.

Dingwall, R., and P. Lewis (eds.). 1983. The sociology of the professions: Doctors, lawyers and others. London: Macmillan.

Driessen, C.P.G. 2012. Farmers engaged in deliberative practices; an ethnographic exploration of the mosaic of concerns in livestock agriculture. Journal of Agricultural Environmental Ethics 25(2): 63-179.
Driessen, C.P.G. 2014. Animal deliberation: The co-evolution of technology and ethics on the farm. PhD Dissertation. Wageningen: Department of Philosophy, Wageningen University.

Dundon, S.J. 2003. Agricultural ethics and multifunctionality are unavoidable. Plant Physiology 133: 427-437.

Hughes, E.C. 1958. Men and their work. New York: Free Press.

EC (European Commission). 1999. Council Directive 1999/74/EC of 19 July 1999, Laying down minimum standards for the protection of laying hens. http://eur-lex.europa.eu/LexUriServ/ LexUriServ.do?uri=OJ:L:1999:203:0053:0057:EN:PDF. Accessed 1 Nov 2014.

EFFAB. 2014. Code-EFABAR 2014/2016. http://www.responsible breeding.eu. Accessed 1 Nov 2014.

Eurostat. 2010. Farm structure evolution, April 2010 data. http://epp. eurostat.ec.europa.eu/statistics_explained/index.php/Farm_struc ture_evolution\#Agricultural_holdings. Accessed 1 Nov 2014.

Evetts, J. 2003. The sociological analysis of professionalism: Occupational change in the modern world. International Sociology 18(2): 395-415.

Evetts, J. 2006. Short note: The sociology of professional groups. Current Sociology 54(1): 133-143.

Evetts, J., and A. Buchner-Jeziorska. 1997. Professionalisation in European markets: The international order of engineering in the UK and Poland. Policy Studies 18(3): 239-249.

Fraser, D. 2001. The "new perception" of animal agriculture: Legless cows, featherless chickens, and a need for genuine analysis. Journal of Animal Sciences 79(3): 634-641.

Fraser, D., D.M. Weary, E.A. Pajor, and B.N. Milligan. 1997. A scientific conception of animal welfare that reflects ethical concerns. Animal Welfare 6: 187-205.

Gottwald, F-Th, H.W. Ingensiep, and M. Meinhardt (eds.). 2010. Food ethics. New York: Springer.

Grimm, H. 2010. Das moralphilosophische experiment. Tübingen: Mohr Siebeck.

Habermas, J. 1990. Moral consciousness and communicative action. Boston, MA: MIT Press.

Harrison, R. 1964. Animal machines: The new factory farming industry. London: Vincent Stuart Ltd.

Haug, M.R., and M.B. Sussman. 1969. Professional autonomy and the revolt of the client. Social Problems 17(2): 153-161.

Hendrickson, M.K., and H.S. James Jr. 2005. The ethics of constrained choice: How the industrialization of agriculture impacts farming and farmer behavior. Journal of Agricultural and Environmental Ethics 18(3): 269-291.

Illich, I. 1977. Disabling professions. London: Marion Boyars.

Knutson, R., J. Penn, and B. Flinchbaugh. 1998. Agricultural and food policy, 4/e ed. Upper Saddle River, NJ: Prentice Hall.

Korthals, M. 2004. Before dinner, philosophy and ethics of food. Dordrecht: Springer.

Kunkel, H.O. 1984. Agriculture ethics-The setting. Agriculture and Human Values 1(1): 20-23.

Lang, T. 1999. Diet, health and globalization: Five key questions. Proceedings of the Nutrition Society 58: 335-343.

Lang, T. 2010. Crisis? What crisis? The normality of the current food crisis. Journal of Agrarian Change 10(1): 87-97.

LTO-Nederland (Netherlands Farmers Association). 2009. Dierenwelzijn: samen verantwoordelijkheid nemen! Visie op dierenwelzijn: update, februari 2009. http://www.lto.nl, Accessed 1 Nov 2014.

McDonagh, J. 2013. Rural geography I: Changing expectations and contradictions in the rural. Progress in Human Geography 37(5): $712-720$

Mcelwee, G., and I. Annibal. 2010. Business support for farmers: an evaluation of the Farm Cornwall Project. Journal of Small Business and Enterprise Development 17(3): 475-491. 
Meijboom, F.L.B. 2008. Problems of trust: A question of trustworthiness: An ethical inquiry of trust and trustworthiness in the context of the agricultural and food sector. Utrecht: Utrecht University.

Meijboom, F.L.B. 2009. Care and responsibility as key concepts of agricultural ethics. In Ethical futures: Bioscience and food horizons, ed. K. Millar, et al., 237-240. Wageningen: Wageningen Academic Press.

Mepham, T.B., G.A. Tucker, and J. Wiseman (eds.). 1995. Issues in agricultural bioethics. Nottingham: University of Nottingham Press.

NFU (National Farmers Union). 2010. NFU successes: Environment, climate change and renewables. http://www.nfuonline.com. Accessed 1 Nov 2014.

Parsons, T. 1954. Essays in sociological theory. London: The Free Press of Glencoe.

Rollin, B.E. 2004. Annual meeting keynote address: Animal agriculture and emerging social ethics for animals. Journal of Animal Science 82(3): 955-964.

Ruttan, V.W. 1999. The transition to agricultural sustainability. PNAS 96(11): 5960-5967.

Schoon, B., and R. te Grotenhuis. 2000. Values of farmers, sustainability and agricultural policy. Journal of Agricultural and Environmental Ethics 12(1): 17-27.

SER/The Social and Economic Council of the Netherlands. 2008. Advisory report-CAP reform and public services of agriculture (2008/05). Netherlands: The Hague.

Singer, P. 1990. Animal liberation. New York: Avon Book. (New Revised Edition).

Stafleu, F.R. 2001. The ethics of cattle breeding. The development of a company policy on ethics. In Food safety, food quality, food ethics, ed. M. Pasquali, 435-438. Milan: University of Milan.

Stafleu, F.R., C.C. de Lauwere, K.H. de Greef, P. Sollie, and S. Dudink. 2004. Boerenethiek, eigenwaarden als basis voor een 'nieuwe ethiek', een inventarisatie. Gravenhagen: NWO.

Te Velde, H., N. Aarts, and C. van Woerkom. 2002. Dealing with ambivalence: Farmers' and consumers' perceptions of animal welfare in livestock breeding. Journal of Agricultural and Environmental Ethics 15(2): 203-219.

Thompson, P. 1990. Agrarianism and the american philosophical tradition. Agriculture and Human Values 7(1): 3-8.
Thompson, P.B. 2013. Agricultural ethics. In The international encyclopedia of ethics, ed. H. LaFollette, 171-177. Malden, Oxford: Wiley-Blackwell.

Van der Ploeg, J.D. 2010. The food crisis, industrialized farming and the imperial regime. Journal of Agrarian Change 10(1): 98-106.

Van der Weele, C., and C. Driessen. 2013. Emerging profiles for cultured meat; ethics through and as design. Animals 3(3): $647-662$.

Van Mill, D. 1996. The possibility of rational outcomes from democratic discourse and procedures. Journal of Politics 58(3): 734-752.

Varley, T., J. McDonagh, and S. Shortall. 2009. The politics of rural sustainability. In A living countryside? The politics of sustainable development in rural Ireland, ed. J. McDonagh, T.J. Varley, and S. Shortall, 1-24. Farnham: Ashgate.

Waltner-Toews, D., and T. Lang. 2000. A new conceptual base for food and agricultural policy: The emerging model of links between agriculture, food, health, environment and society. Global Change \& Human Health 1(2): 116-130.

Wilensky, H.L. 1964. The professionalization of everyone? American Journal of Sociology 70(2): 137-158.

ZLTO. 2009. Startdocument ZLTO Visie 2010-2020, vol. 17-122009. Den Bosch: Zuidelijke Land- en Tuinbouworganisatie.

Franck L. B. Meijboom Ph.D., is assistant professor in ethics at the Ethics Institute and at the Department of Animals in Science and Society of the Faculty of Veterinary Medicine, Utrecht University. He focuses on agricultural and food ethics, animal ethics, and the role of public trust and debate in these domains. Additionally, he is chair and member of a number of ethics committees (e.g., Royal Netherlands Veterinary Society) and he is Secretary of the European Society for Agricultural and Food Ethics (EurSafe).

Frans Stafleu Ph.D., is assistant professor at the Ethics Institute of Utrecht University. His research on livestock farming and animal testing focuses on applied ethical questions and explores the relation between biology and ethics. 